\title{
Chimeric Proteins to Detect DNA Damage and Mismatches
}

\author{
S.L. McCutchen-Maloney, M. Malfatti, and K.M. Robbins
}

\section{January 14, 2002}

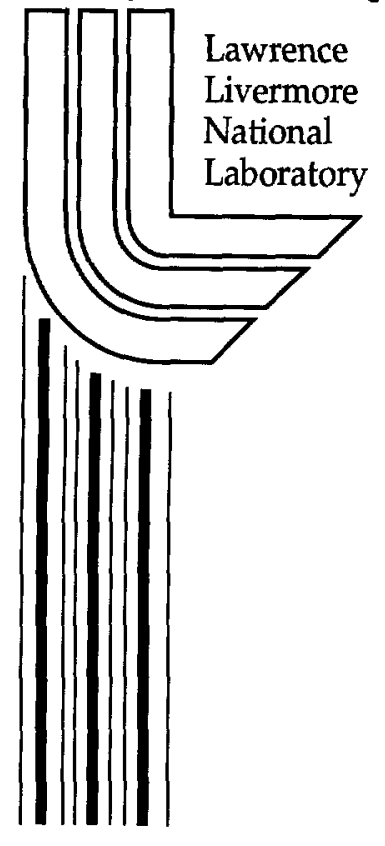




\section{DISCLAIMER}

This document was prepared as an account of work sponsored by an agency of the United States Government. Neither the United States Government nor the University of California nor any of their employees, makes any warranty, express or implied, or assumes any legal liability or responsibility for the accuracy, completeness, or usefulness of any information, apparatus, product, or process disclosed, or represents that its use would not infringe privately owned rights. Reference herein to any specific commercial product, process, or service by trade name, trademark, manufacturer, or otherwise, does not necessarily constitute or imply its endorsement, recommendation, or favoring by the United States Government or the University of California. The views and opinions of authors expressed herein do not necessarily state or reflect those of the United States Government or the University of California, and shall not be used for advertising or product endorsement purposes.

This work was performed under the auspices of the U. S. Department of Energy by the University of California, Lawrence Livermore National Laboratory under Contract No. W-7405-Eng-48.

This report has been reproduced directly from the best available copy.

Available electronically at $h t t p: / / w w w . d o c . g o v / b r i d g e$

Available for a processing fee to U.S. Department of Energy

And its contractors in paper from

U.S. Department of Energy

Office of Scientific and Technical Information

P.O. Box 62

Oak Ridge, TN 37831-0062

Telephone: (865) 576-8401

Facsimile: (865) 576-5728

E-mail: reports@adonis.osti.gov

Available for the sale to the public from

U.S. Department of Commerce

National Technical Information Service

5285 Port Royal Road

Springfield, VA 22161

Telephone: (800) 553-6847

Facsimile: (703) 605-6900

E-mail: orders@ntis.fedworld.gov

Online ordering: http://www.ntis.gov/ordering.htm

OR

Lawrence Livermore National Laboratory

Technical Information Department's Digital Library

http://www.llnl.gov/tid/Library.html 


\section{Chimeric Proteins to Detect DNA Damage and Mismatches}

Principal Investigator: Sandra McCutchen-Maloney

Competency: Biotechnology and Health Care Technologies

Tracking Code: 99-LW-004

\section{Annual Report Authors:}

\section{S.L. McCutchen-Maloney, M. Malfatti, K.M. Robbins}

\section{Annual Report Text:}

The goal of this project was to develop chimeric proteins composed of a DNA mismatch or damage binding protein and a nuclease, as well as methods to detect DNA mismatches and damage. We accomplished this through protein engineering based on using polymerase chain reactions (PCRs) to create chimeras with novel functions for damage and mismatch detection.

This project addressed fundamental questions relating to disease susceptibility and radiation-induced damage in cells. It also supported and enhanced LLNL's competency in the emerging field of proteomics.

In nature, DNA is constantly being subjected to damaging agents such as exposure to ultraviolet (UV) radiation and various environmental and dietary carcinogens. If DNA damage is not repaired however, mutations in DNA result that can eventually manifest in cancer and other diseases. In addition to damage-induced DNA mutations, single nucleotide polymorphisms (SNPs), which are variations in the genetic sequence between individuals, may predispose some to disease.

As a result of the Human Genome Project, the integrity of a person's DNA can now be monitored. Therefore, methods to detect DNA damage, mutations, and SNPs are useful not only in basic research but also in the health and biotechnology industries. Current methods of detection often use radioactive labeling and rely on expensive instrumentation that is not readily available in many research settings. Our methods to detect DNA damage and mismatches employ simple gel electrophoresis and flow cytometry, thereby alleviating the need for radioactive labeling and expensive equipment.

In FY2001, we explored SNP detection by developing methods based on the ability of the chimeric proteins to detect mismatches. Using multiplex assays with flow cytometry and fluorescent beads to which the DNA substrates where attached, we showed that several of the chimeras possess greater affinity for damaged and mismatched DNA than for native DNA. This affinity was demonstrated in assays in which we looked both at (1) preferential degradation of damaged or mismatched DNA after addition of a chimeric protein, and (2) preferential binding of the chimeric proteins to damaged or mismatched DNA. 
In our experiments, we used various samples containing damage or mismatches and a control sample containing no damage or mismatches. When a chimeric protein was added to the DNA samples, the damage- or mismatch-recognition portion of the chimeric protein bound the samples containing the DNA damage or mismatch, allowing the nuclease portion to degrade the DNA. Thus, we measured both the preferential binding to the damaged or mismatched DNA and the preferential degradation of these same samples. We showed this in gel-based assays as well as in multiplex flow-cytometry assays.

This year, we also focused on a thermophilic protein, MutS, which in nature functions to detect mistakes in DNA replication by its mismatch-detection capability in an organism that lives under extreme thermal conditions $\left(75^{\circ} \mathrm{C}\right)$. Because of its thermophilic stability, this protein has great potential as a SNP detection tool. However, the results of our multiplex experiments were unclear-potentially because of interference between samples on different beads.

In summary, our results using chimeric proteins and MutS suggest that the proteins and methods developed in this project have application for detecting SNPs and DNA damage as well as for genetic testing.

Two companies have contacted us regarding the patents however no licensing agreements have been established.

Does your current text contain possible patentable material? Yes. I have been working with the patent office and two patents have been files.

Publications - one manuscript in preparation 